\title{
BEHAVIOR OF CORTISOL, CK AND LACTATE IN A SESSION OF VARIABLE RESISTANCE
}

\author{
COMPORTAMENTO DO CORTISOL, CQ E LACTATO EM UMA SESSÃO DE RESISTÊNCIA VARIÁVEL
}

Original Article ARTIGO ORIGINAL COMPORTAMIENTO DEL CORTISOL, CKY LACTATO EN UNA SESIÓN DE RESISTENCIA VARIABLE Artículo Original

Álvaro Huerta Ojeda

(Physical Education Professional) ${ }^{1,5,6}$

Luis Chirosa Ríos

(Physical Education Professional) $^{2}$

Rafael Guisado Barrilao

(Orthopaedic Surgeon) $)^{3}$

Ximena Huerta Ojeda

(Hematologist) $^{4}$

1. Universidad de Las Américas, Facultad de Educación, Escuela de Educación Física, Viña del Mar, Chile. 2. Universidad de Granada, Department of Physical Education and Sport, Spain.

3. Universidad de Granada, Facultad de la Salud, Granada, Spain.

4. Hospital Carlos Van Buren, Department of Medicine,

Valparaíso, Chile.

5. Centro de Capacitación e Investigación Deportiva Alpha Sports, Valparaíso, Chile. 6. Universidad de Las Americas, Escuela de Educacion Fisica, Grupo de Investigacion en Salud, Actividad Fisica y Deporte ISAFYD,

Vina del Mar, Chile.

\section{Correspondence:}

Rodolfo Phillipi 129, Departamento 407A, Valparaíso, Chile. achuertao@yahoo.es

\begin{abstract}
Introduction: Complex Training (CT) has been used to achieve Post-activation Potentiation (PAP) of physical capabilities and, in doing so, improve the sports performance of athletes. However, few studies have considered alterations in serum Cortisol, Metabolic Creatine Kinase (MB-CK), Total Creatine Kinase (Total-CK), and Lactate concentrations ([La]) resulting from this training method. Objective: This study determined the behavior of the following blood serum substances in a CT session: Cortisol, MB-CK, Total CK and [La]. Method: Ten military athlete volunteers aged $28.5 \pm 4.8$ years; $66.2 \pm 2.8 \mathrm{~kg}, 171.4 \pm 3.7 \mathrm{~cm}, 22.6 \pm 1.2 \mathrm{~kg} / \mathrm{m}^{2} ; 11.3 \pm$ $2.9 \%$ of fat tissue took part in the study. The study had a quasi-experimental, intrasubject design. The variable measurements were: Cortisol, MB-CK, Total-CK, and [La], measured before physical exercise and 24 hours post-stress. The CT session consisted of: four series of five repetitions at 30\% of 1RM, plus four repetitions at $60 \%$ of 1 RM, plus three throws of a $575 \mathrm{~g}$ projectile, 15 seconds apart. The statistical analysis was carried out through repeated measure ANOVA for Lactate and a Wilcoxon Matched Pairs t-Test for Cortisol, MB-CK and Total-CK. Results: There was no evidence of alterations in the indicators for fatigue ([La] $p=0.36$ ), and muscular injury (Cortisol $p=0.16$; MB-CK $p=0.23$; Total-CK $p=0.64$ ) after the training sessions. Conclusion: Variables for muscular injury showed no evidence of alterations 24 hours after the CT sessions, hence confirming that the workload did not generate significant post-stress muscular injury. Level of Evidence l; Therapeutic Study: Investigating Treatment Results.
\end{abstract}

Keywords: Exercise; Upper Extremity; Cortisol; Creatine Kinase; Lactates.

\section{RESUMO}

Introdução: Os exercícios de Resistência Variável (RV) têm sido utilizados para aumentar a potencialização pós-ativação (PPA) das habilidades físicas e, com isso, melhorar o desempenho desportivo dos atletas, mas poucos estudos se referem às alterações sanguíneas do Cortisol, Creatina Quinase Metabólica (CQ-MB), Creatina Quinase Total (CQ-Total) e concentrações de Lactato ([La]), que provocam esse método de treinamento. Objetivo: Este estudo avaliou o comportamento sanguíneo do Cortisol, CQ-MB, CQ-Total e [La] em um treinamento de RV. Métodos: Dez atletas militares voluntários com 28,5 $\pm 4,8$ anos; $66,2 \pm 2,8 \mathrm{Kg} ; 171,4 \pm 3,7 \mathrm{~cm} ; 22,6 \pm 1,2 \mathrm{Kg} / \mathrm{m}^{2}$ e 11,3 $\pm 2,9 \%$ de tecido adiposo fizeram parte do estudo. O projeto foi quase experimental intra-sujeito. As medidas variáveis foram: Cortisol, CQ-MB, CQ-Total e [La], medidos antes e 24 horas após o esforço. O treinamento de intervenção com RV consistia em: quatro séries de cinco repetições de 30\% de 1RM, mais quatro repetições de 60\% de 1 RM, mais três lançamentos de um projetil de $575 \mathrm{~g}$, separados por 15 segundos. A análise estatística foi realizada através de médias repetidas ANOVA para Lactato e um Teste t de Wilcoxon Matched para o Cortisol, CQ-MB e CQ-Total. Resultados: Aplicado o treinamento, não foram evidenciadas alterações nos indicadores de fadiga ([La] $p=0,36$ ) e lesão muscular (Cortisol $p=0,16 ; M B-C Q p=0,23 ; C Q-T o t a l ~ p=0,64$ ). Conclusão: O treinamento com RV não apresentou alterações nas variáveis de lesão muscular após 24 horas da sua aplicação, isso garante que as cargas de trabalho não gerem lesões musculares significativas pós-esforço. Nível de Evidência l; Estudo terapéutico: Investigação dos resultados do tratamento.

Descritores: Exercício; Extremidade Superior; Cortisol; Creatina Quinase; Lactatos.

\section{RESUMEN}

Introducción: La Resistencia Variable (VR) es un método de entrenamiento que ha sido utilizado para conseguir Potenciación Post Activación de las capacidades físicas y, con esto, mejorar el rendimiento deportivo de atletas, no obstante, pocos estudios se refieren a las alteraciones sanguíneas de Cortisol, Metabolic Creatine Kinase (CK-MB), Creatine Kinase Total (CK-Total) y concentraciones de Lactato ([La]) que este método provoca. Objetivo: Este estudio determinó el comportamiento sanguíneo del Cortisol, CK-MB, CK-Totaly [La] en una sesión de VR. Método: Diez atletas militares voluntarios con $28,5 \pm 4,8$ años, $66,2 \pm 2,8 \mathrm{Kg}, 171,4 \pm 3,7 \mathrm{~cm}, 22,6 \pm 1,2 \mathrm{Kg} / \mathrm{m}^{2} ; 11,3 \pm 2,9 \%$ de tejido graso, fueron parte del estudio. El diseño fue cuasi experimental intrasujeto. Las variables medidas fueron: Cortisol, CK-MB, CK-Totaly [La], evaluadas 24 horas antes y 24 horas post esfuerzo. La sesión de intervención con VR consistió en: cuatro series de cinco repeticiones al 30\% de 1RM más cuatro repeticiones al 60\% de 1 RM más tres lanzamientos de un proyectil de $575 \mathrm{~g}$ separadas por 15 segundos. El análisis estadístico fue realizado a través de una ANOVA de medias repetidas para el Lactato y con un 
Test t de Wilcoxon Matched para el Cortisol, CK-MB y CK-Total. Resultados: Aplicado el tratamiento no se evidenciaron alteraciones en los indicadores de daño muscular (Cortisol $p=0,16 ; \mathrm{MB}-\mathrm{CK} p=0,23 ;$; $C$-Total $p=0,64$ ) nifatiga ([La] $p=$ 0,36). Conclusiones: El tratamiento con VR no dejó en evidencia alteraciones en las variables de daño muscular a 24 horas de su aplicación, asegurando que las cargas de trabajo no generan daño muscular significativo post esfuerzo. Nivel de Evidencia l; Estudio terapéutico: Investigación de los resultados de un tratamiento.

\section{Descriptores: Ejercicio; Extremidad Superior; Cortisol; Creatina Quinasa; Lactatos.}

\section{INTRODUCTION}

The high sport levels achieved today, have been achieved by applying various training methodologies; some of them with plyometric exercises, ${ }^{1}$ isometry, ${ }^{2,3}$ incremental series, ${ }^{4,5}$ force series, ${ }^{6,7}$ variable resistances (VR), ${ }^{8}$ among others. In the vast majority of cases, these training methods cause negative organic alterations in athletes, even more if we consider untrained subjects, who begin physical activity 9 . Unfortunately, the level of muscle damage generated by each of these methods isn't fully documented, therefore, along with assessing the increase in physical abilities, it is also necessary to assess the indicators of fatigue and muscle damage ${ }^{10}$.

A modern method of training capable of increasing the explosive force is the Post Activation Potentiation (PAP) ${ }^{11}$. This PAP can be caused by different forms of activation, including $V R^{12,13}$. This activation with VR also has been defined as contrast or complex training ${ }^{8}$. There are some authors who has used VR in order to find PAP of physical capacities 1,5,8,12-14, and with this improve the athletic performance to athletes, but there are few studies that have assessed the levels of fatigue associated with lactate concentrations ([La]) in blood and muscle damage caused by the use of VR, evidenced through Creatine Kinase (CK) levels ${ }^{10,15,16}$.

Therefore, and due to the lack of existing evidence in this regard, it is important to determine whether training loads based on VR, together with increasing levels of explosive force, cause fatigue or negative organic alterations in an acute manner (24 hours post effort). ${ }^{10,16} \mathrm{n}$ the reviews conducted there are few conclusive studies that triggered PAP, along with evidence of levels of fatigue and muscle damage after a VR treatment in power zones (60-80\% of 1RM)..$^{10}$ Apparently, the activation with VR in power zones triggers PAP to increase the explosive force, ${ }^{12}$ but it isn't certain what levels of fatigue are presented during the training session or the possible muscular damages generated in the muscles involved in the training sports.

Based on the foregoing, the main objective of the present study was to determine the blood behavior of Cortisol, CK Metabolic, Total CK and [La] after the application of a VR protocol $(5 \times 30 \%$ of $1 \mathrm{RM}+4 \times$ $60 \%$ of 1 RM in bench press +3 launching of grenade with pause of 15 seconds) at 24 hours post effort spending. The secondary objective was to determine the acute effect of a VR protocol in bench press upon the distance of the launching of grenade.

\section{MATERIALS AND METHOD}

Ten athletes belonging to the Chilean Navy (28,5 $\pm 4,8$ years, 66,2 \pm $2,8 \mathrm{Kg}, 171,4 \pm 3,7 \mathrm{~cm}, 22,6 \pm 1,2 \mathrm{Kg} / \mathrm{m}^{2}, 11,3 \pm 2,9 \%$ of body fat) were part of the study. All the athletes and coaches were informed the objectives of the study and the possible risks of the experiment; all signed an informed consent before the application of the treatment. The informed consent and the study were approved by the Human Research Committee of the University of Granada, Spain (record number 933).

The study was lead in the specific period of the annual work curve, and in this way, the VR training coupled with the demands of the coaches. The inclusion criterion was that all participants had at least two years representing the Chilean Navy before the study.

\section{Procedures}

For all the participants in the research was asked to refrain from ingesting caffeine, medications and any substance that increased metabolism during the entire experiment.

The study had a quasi-experimental design, intrasubject, with test and post-test.

Both the $1 \mathrm{RM}(\mathrm{Kg})$ valuation as the maximum power (watts) and average power (watts) of the Bench Press during the application of the VR protocol, were evaluated with the CHRONO JUMP Linear Encoder through the software CHRONOJUMP Version 1.4.6.0. To obtain Indirect 1RM, it was used the formula proposed by Sanchez-Medina et al. (2010). ${ }^{17}$ Then, 48 hours after the 1RM evaluation, the control series was carried out (SC). This SC has intended to verify the power zone of each athlete. ${ }^{18}$ The SC consisted of $1 \times 4$ to $60 \%$ of 1 RM. During the experiment, the VR protocol $(5 \times 30 \%$ of $1 \mathrm{RM}+4 \times 60 \%$ of $1 \mathrm{RM}$ in Bench Press +3 Launches of Grenade with pause of $15 \mathrm{~s}$ ) was monitored in both its light loads ( $5 \mathrm{x}$ $30 \%$ of 1 RM) as in their heavy loads ( $4 \times 60 \%$ of 1 RM); this allowed to verify the appearance of fatigue during the development of the intervention.

The post-effort was evaluated with the h/p/Cosmos Sirius ${ }^{\circ}$ meter that generates an enzymatic-amperometric detection of lactate with an accuracy of $\pm 3 \%$ (minimum standard deviation of $0,2 \mathrm{mmol} / \mathrm{L}$ ), sample volume 0,2 $\mu \mathrm{L}$ and with a measurement range of 0,5 - 25,0 mmol/L. Lactate was measured at the end of the third grenade launch, both in the SC and in the four experimental series.

After the assessment of 1RM, before and after the application of the protocol with VR, all the participants were evaluated the biochemical profile. Tests consisting of the assessment of Cortisol, Creatine Kinase Metabolic (CK-MB) and Creatine Kinase Total (CK-Total), were used to assess the level in the blood of the muscle damage indicators generated by the VR protocol.

For the CK-MB and the CK-Total, the blood analysis performed through the enzymatic method. For Cortisol, the method used was Chemiluminescent Microparticle Immunoassay. All measurements and analyzes were performed at the Naval Hospital of the Chilean Navy.

All the biochemical profile assessments were carried out in fasting; in addition, there was a wash up (wash up) of 48 hours before the first measurement (Baseline).

In the study, two measurements were used; the first one corresponds to the Base Measurement (Baseline), and the second 24 hours after the application of the VR protocol. (Figure 1)

For the characterization of the sample, weight and height were measured with the Health Balance and Stadiometer or Meter Professional ${ }^{\circledR}$. This balance can measure up to $204 \mathrm{Kg}$ and has a rod that goes from 60 to $214 \mathrm{~cm}$ in height. Skin folds were measured with an F.A.G.A ${ }^{\circledR}$ caliper that has a constant pressure of $10 \mathrm{~g} / \mathrm{mm}^{2}$. The skin folds measured to determine the fat percentage were the Biceps, Triceps, Subscapular and Supra Spinal using the method of e Durnin \& Womersley (1974). ${ }^{19}$

The warm-up for the evaluation of 1RM, the SC and the application of the experimental protocol consisted of 10 minutes of trotting. The first five minutes were free trotting and the remaining five minutes included 

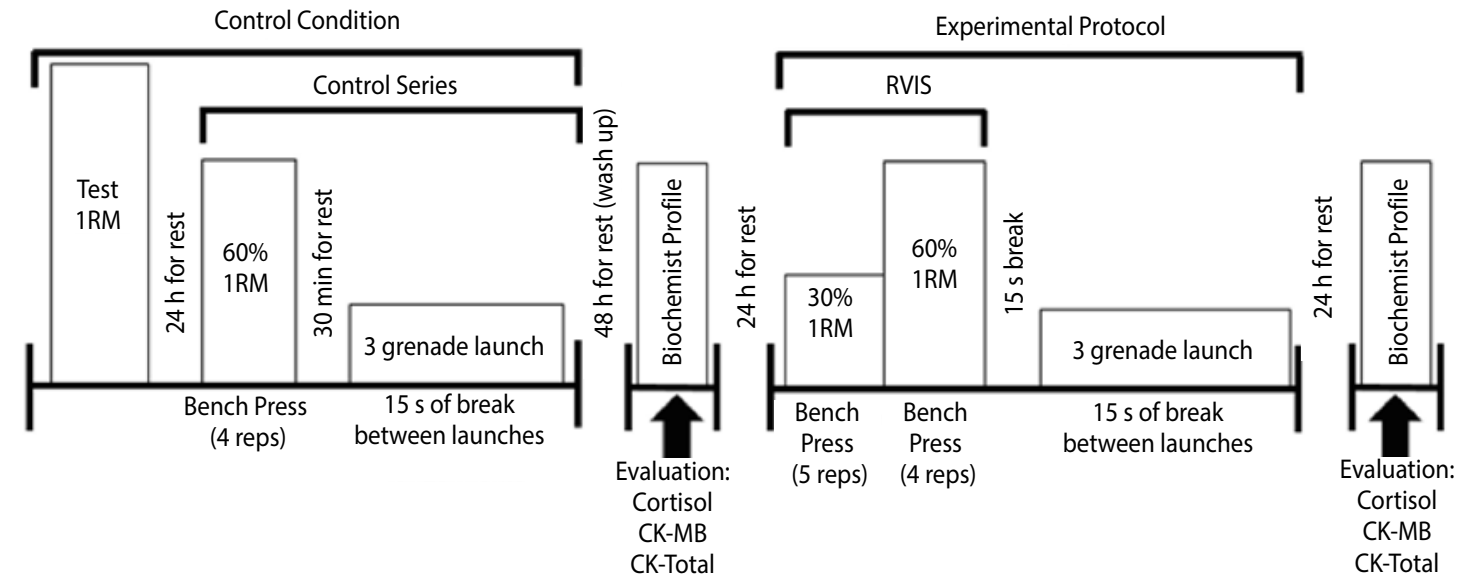

1RM (a maximum repetition); reps (repetitions); RVIS (intra-series variable resistance); \% (percent); min (minutes); s (seconds); CK-MB (Metabolic Creatine Kinase); CK-Total (Total Creatine Kinase).

Figure 1. Sequence of the experimental protocol.

ballistic movements of the upper extremity (push-ups, extensions, adductions and shoulder abductions).

Job program: included the 1RM evaluation; after this, $60 \%$ of 1 RM was checked (a series of four repetitions). The purpose of this was to corroborate whether the subjects were in the optimal power zone ${ }^{18}$; this values of maximum power and average power were also considered as SC. After finished the test of $60 \%$ of $1 \mathrm{RM}$, all the subjects were measured in the [La].

The experimental protocol consisted of: four sets of five repetitions at $30 \%$ of $1 \mathrm{RM}$, plus four repetitions at $60 \%$ of $1 \mathrm{RM}$, with pause of five seconds, plus three launches of one projectile of $575 \mathrm{~g}$ separated by 15 seconds (5 $\times 30 \%$ of 1 RM $+4 \times 60 \%$ of 1 RM in Bench Press +3 Launchings of Grenade with 15-s pause); immediately after the last release, both the $\mathrm{SC}$ and the four experimental series were measured lactate to all athletes. (Figure 2)

\section{Statistical analysis}

The test Kolmogorov-SEirnov (K-S) it was used for the analysis of the normality of the data, while for the statistical analysis of Cortisol, CK-MB and CK-Total, the Test t of Wilcoxon Matched. Finally, for the analysis of the [La] and the average distance of the launch of the grenade, ANOVA of repeated averages was used. The level of significance for all analyzes was $p<0.05$. The data analysis was performed with the software GraphPad InStat Version $3.05^{\circ}$.

\section{RESULTS}

After 24 hours from the application of the VR protocol in the Banking Press, the concentrations of Cortisol, CK-MB and CK-Total blood didn't show significant changes ( $p>0.05$ ). The results of the SC (Baseline) and the experimental protocol are shown in Table 1 and Figures 3, 4 and 5.

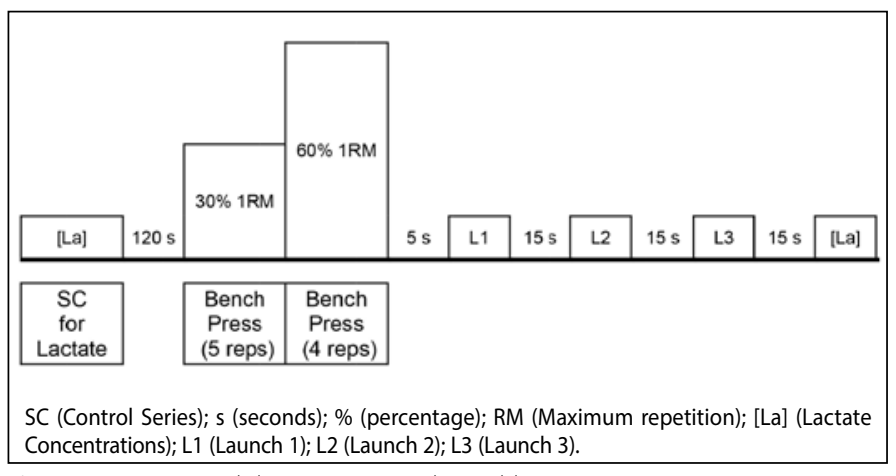

Figura 2. Experimental design session with Variable Resistance Intra-Series.
Table 1. Results (average \pm DS) of the muscle damage indicators before and after the application of the experimental protocol of Variable Resistance in Bench Press.

\begin{tabular}{c|c|c|c|c|c}
\hline Variables & Baseline & E1 & CV (\%) & $\boldsymbol{\Delta}$ & p Value \\
\hline CK-MB (U/L) & $22,8 \pm 7,9$ & $20,0 \pm 2,8$ & $-12,3$ & $-2,8$ & 0,23 \\
\hline CK-Total $(\mathrm{U} / \mathrm{L})$ & $233,4 \pm 178,4$ & $209,6 \pm 74,2$ & $-10,2$ & $-23,8$ & 0,64 \\
\hline Cortisol $(\mu \mathrm{g} / \mathrm{d} \mathrm{l})$ & $9,8 \pm 1,6$ & $10,6 \pm 1,3$ & 7,9 & 0,7 & 0,16 \\
\hline
\end{tabular}

E1 (Experimental Protocol); CK-MB (Metabolic Kinase Creatine); CK-Total (Total Creatine Kinase); U/L (units per liter); DS (Standard Deviation); $\mu \mathrm{g} / \mathrm{dl}$ (micrograms per liter); $\Delta$ (difference between Baseline and Experimental Protocol in absolute values); CV (Coefficient of Variation between Baseline and Experimental Protocol in percentages).

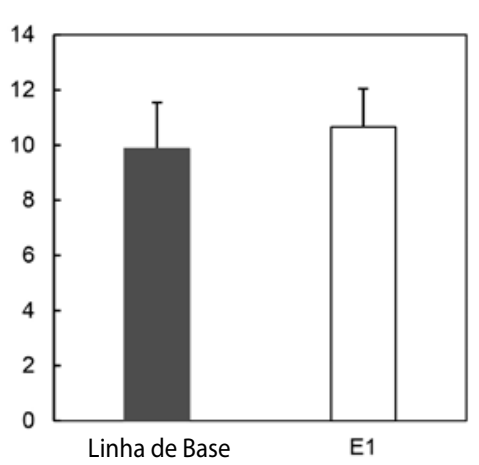

$\mu \mathrm{g} / \mathrm{dL}$ (micro gramos por litro); E1 (Protocolo Experimental).

Figure 3. Cortisol levels in Test (Baseline) and Post Test (E1).

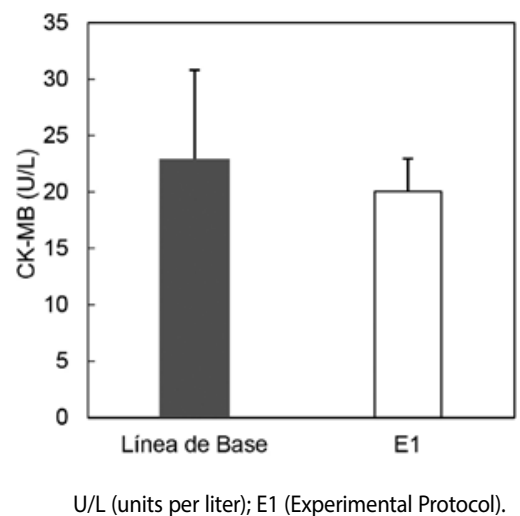

Figure 4. Levels of Metabolic Creatine Kinase in Test (Baseline) and Post Test (E1). 
Regarding the [La] post-effort, no significant changes were observed between the SC and the four experimental series ( $p>0.05$ ); while the average distances at the launch of the grenade showed a significant increase between the SC and the four experimental series. The results of the SC and the four experimental series for both variables are shown in Table 2, Figure 6.

\section{DISCUSSION}

In relation to the main objective of this study, it was determined that 24 hours after applying a VR protocol in Bench Press, there were no significant changes in blood concentrations of Cortisol, CK-MB, CKTotal or Lactate. However, in most of the studies consulted, the different

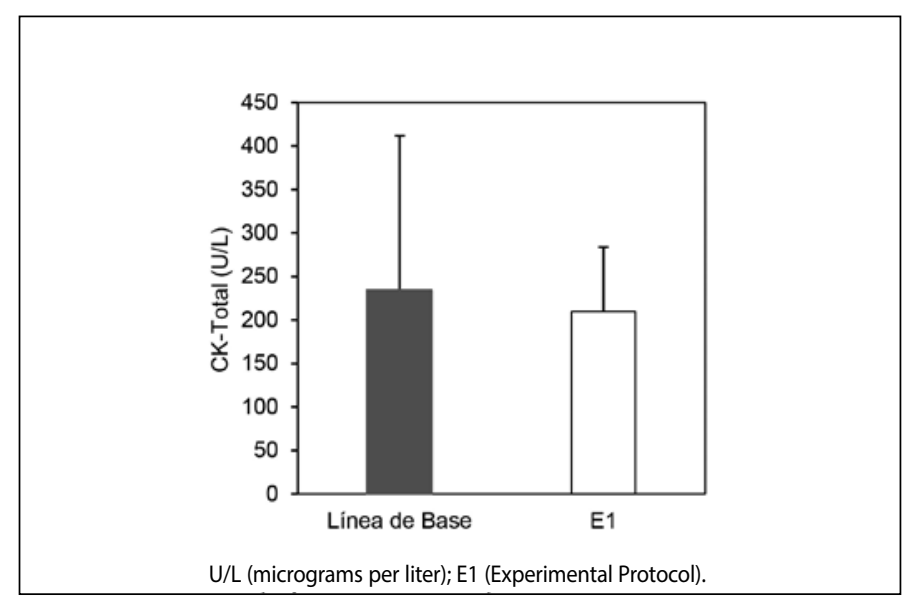

Figure 5. Total Creatine Kinase Levels in Test (Baseline) and Post Test (E1).

Table 2. Results (media \pm DS) for [La] and the distances of launch of the grenade after the activation with Variable Resistance in Bench Press.

\begin{tabular}{c|c|c|c|c|c|c}
\hline Variable & $\begin{array}{c}\text { Control } \\
\text { Series }\end{array}$ & Series 1 & Series 2 & Series 3 & Series 4 & $\begin{array}{c}\text { ANOVA } \\
\mathbf{p}\end{array}$ \\
\hline$[\mathrm{La}](\mathrm{mmol} / \mathrm{L})$ & $1,92 \pm 0,33$ & $1,90 \pm 0,30$ & $1,99 \pm 0,34$ & $1,97 \pm 0,31$ & $2,08 \pm 0,33$ & 0,36 \\
\hline $\mathrm{D} \mathrm{pro} \mathrm{(m)}$ & $36,19 \pm 6,8$ & $33,96 \pm 7,3$ & $34,14 \pm 6,1$ & $33,64 \pm 6,6$ & $31,37 \pm 7,1$ & $*$ \\
\hline
\end{tabular}

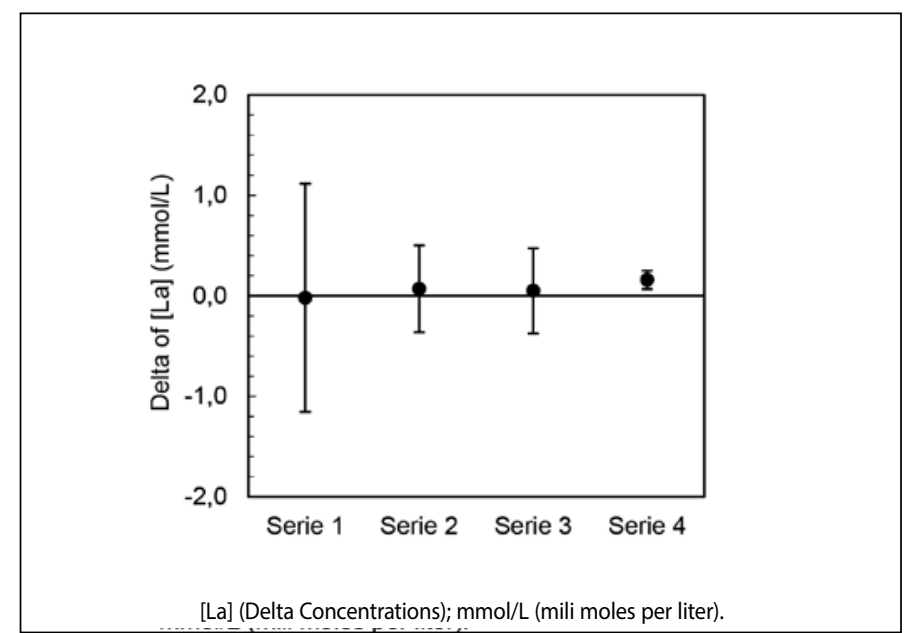

Figure 6. Delta of lactate concentrations between the control series and the four experimental series. interventions generated increases in both energy metabolism markers such, as [La] ${ }^{20-22}$ or markers of muscle damage such as $\mathrm{CK}^{23-25}$ In that sense, at the end of the investigation, West et al. ${ }^{26}$ evidenced increases in the [La] post effort ( $<<0,0001)$; similarly, Cadore et al. ${ }^{27}$ reported significant increases in [La] after workload. On the other hand, Walker et al. ${ }^{16}$ observed the fatigue indexes after the chronic effects of $V R$ in PAP, finding significant increases in active force $(p<0.05)$, but also significant increases in muscle fatigue after activation with VR $(p<0,05)$. In contrast to the mentioned authors, in the present study there were no significant changes in the [La] after the application of the VR protocol in the Bench Press $(p=0,36)$. This allows us to infer that the activation loads performed by the athletes don't induce general fatigue (four sets of five repetitions at $30 \%$ of $1 \mathrm{RM}$, plus four repetitions at $60 \%$ of $1 \mathrm{RM}$, with a pause of five seconds).

In the same line, after the application of the exercise protocols, Aboodarda et al. ${ }^{28}$ evidenced post-effort muscle damage, while Peltronen et al..$^{15}$ used electromyography as a parameter of muscular fatigue. In both studies, post-effort local muscle damage was reported. ${ }^{15,28}$ However, in an investigation developed by Silva et al. ${ }^{29}$ where a 70\% treatment of 1RM was applied, there was no significant change in blood levels of Cortisol at 72 hours post effort $(p>0,05)$. In the same way, Schultz et al. ${ }^{30}$ didn't report significant increases in blood levels of Cortisol in athletes during a 40-day preparatory phase $(p>0,05)$. In the present study, and after 24 hours of rest after the application of the treatment based on VR, no significant alterations were observed in the muscle damage indicators (Cortisol $p>0,05$, CK-MB p > 0,05; CK-Total $p>0,05$ ). Consequence of the above, applying a VR protocol in the Bench Press doesn't cause negative alterations in athletes.

In relation to the secondary objective of this investigation, a positive acute effect of a VR protocol was determined in the Bench Press about the distance of the launch of the grenade $(p<0.05)$. At the end of the intervention, the athletes showed an increase in the explosive strength of the upper extremity. This increase in the distance of the grenade observed in the present study is attributed to the PAP of the muscles activated with VR. ${ }^{11}$ Although activation with VR to trigger PAP is a little studied methodology, ${ }_{1}^{13}$ in a study developed by Huerta et al., ${ }^{12}$ was evidenced changes in the explosive strength of the lower extremity after the application of a VR protocol in squats. The authors reported significant changes in the time of 30 meters flat. ${ }^{12}$

\section{CONCLUSIONS}

At the end of the study, and after the application of the Bench Press protocol, no significant changes were observed in the blood concentrations of Cortisol, CK-MB, CK-Total or Lactate. These antecedents allow to assure that to the 24 hours of post effort, all the athletes were in anabolic process, clearing possible symptoms of over training. To this is added that after the application of the VR protocol in Bench Press, the athletes showed an explosive increase of force (throwing the grenade). Therefore, VR seems to be a good measure to achieve increases in sports performance, as it generated PAP in the muscles involved and also didn't cause muscle damage.

All authors declare no potential conflict of interest related to this article.

AUTHORS' CONTRIBUTIONS: Each author made significant individual contributions to this manuscript. AHO (0000-0001-6871-098X)* and LCR (0000-0002-1008-176X)* were the main contributors to the writing of the manuscript. RGB (0000-0003-1855-0038)*and XHO (0000-0002-4885-7658)* performed the data acquisition and statistical analysis. AHO and LCR performed the bibliographic search and review of the manuscript, and contributed to the intellectual concept of the study. All authors approved the final version of the manuscript. *ORCID (Open Researcher and Contributor ID). 


\section{REFERENCES}

1. García-Pinillos F, Martínez-Amat A, Hita-Contreras F, Martínez-López E, Latorre-Román P. Effects of a contrast training program without external load on vertical jump, kicking speed, sprint, and agility of young soccer players. J Strength Cond Res. 2014;28(9):2452-60.

2. Arabatzi F, Patikas D, Zafeiridis A, Giavroudis K, Kannas T, Gourgoulis V, et al. The post-activation potentiation effect on squat jump performance: age and sex effect. Pediatr Exerc Sci. 2014;26(2):187-94

3. Tsolakis C, Bogdanis GC, Nikolaou A, Zacharogiannis E. Influence of type of muscle contraction and gender on postactivation potentiation of upper and lower limb explosive performance in elite fencers. J Sport Sci Med. 2011;10(3):577-83.

4. Argus CK, Gill ND, Keogh JW, McGuigan MR, Hopkins WG. Effects of two contrast training programs on jump performance in rugby union players during a competition phase. Int I Sport Physiol Perform 2012;7(1):68-75.

5. Hirayama K. Acute effects of an ascending intensity squat protocol on vertical jump performance. J Strength Cond Res. 2014;28(5):1284-8.

6. Naclerio F, Faigenbaum A, Larumbe-Zabala E, Ratamess N, Kang J, Friedman P, et al. Effectiveness of different postactivation potentiation protocols with and without whole body vibration on jumping performance in college athletes. J Strength Cond Res. 2014;28(1):232-9.

7. Seitz LB, de Villarreal ES, Haff GG. The temporal profile of postactivation potentiation is related to strength level. J Strength Cond Res. 2014;28(3):706-15.

8. Talpey SW, Young WB, Saunders N. The acute effects of conventional, complex, and contrast protocols on lower-body power. J Strength Cond Res. 2014;28(2):361-6.

9. Flann K, LaStayo P, McClain D, Hazel M, Lindstedt S. Muscle damage and muscle remodeling: No pain, no gain? J Exp Biol. 2011;214(Pt 4):674-9.

10. Ojeda ÁH, Ríos LC, Barrilao RG, Serrano PC. Effect of two complex training protocols of back squats in blood indicators of muscular damage in military athletes. J Phys Ther Sci. 2016;28(5):1487-92.

11. Sale D. Postactivation potentiation: role in performance. Br J Sports Med. 2004;38(4):386-7.

12. Ojeda ÁH, Ríos LC, Barrilao RG, Serrano PC. Acute effect of a complex training protocol of back squats in 30-m sprint times of elite male military athletes. J Phys Ther Sci. 2016;28(3):752-6.

13. Huerta A, Chirosa L, Guisado R, Chirosa I, Cáceres P. Efecto de la resistencia variable sobre la potenciación post activación: una revisión sistemática. Arch Med Deporte. 2016;33(5):337-44.

14. Gómez-Navarrete J, Solana R, Horrillo J, Murillo D. Influencia aguda de la aplicación de un tratamiento de fuerza basado en el método de contrastes combinado, sobre la precisión y la velocidad del lanzamiento en balonmano. E-balonmano.com: Revista de Ciencias del Deporte. 2011;7(1):5-16.

15. Peltonen H, Walker S, Hakkinen K, Avela J. Neuromuscular fatigue to power loading using a weight-stack device fitted with or without additional rubber band resistance. J Strength Cond Res. 2014;28(7):1802-11.
16. Walker S, Ahtiainen J, Häkkinen K. Acute neuromuscular and hormonal responses during contrast loading: effect of 11 weeks of contrast training. Scand J Med Sci Sports. 2010;20(2):226-34.

17. Sanchez-Medina L, Perez CE, Gonzalez-Badillo JJ. Importance of the propulsive phase in strength assessment. Int J Sports Med. 2010;31(2):123-9.

18. Bautista IJ, Chirosa IJ, Chirosa LJ, Martín I, González A, Robertson RJ. Development and validity of a scale of perception of velocity in resistance exercise. J Sport Sci Med. 2014;13(3):542-9.

19. Durnin J, Womersley J. Body fat assessed from total body density and its estimation from skinfold thickness: measurements on 481 men and women aged from 16 to 72 years. Br J Nutr. 1974;32(01):77-97.

20. Ferraz R, Van Den Tillaar R, Marques M. The Effect of Fatigue on Kicking Velocity in Soccer Players. J Hum Kinet. 2012;35(1):97-107.

21. Meckel Y, Nemet D, Bar-Sela S, Radom-Aizik S, Cooper D, Sagiv M, et al. Hormonal and inflammatory responses to different types of sprint interval training. J Strength Cond Res. 2011;25(8):2161-9.

22. Ojala T, Häkkinen K. Effects of the tennis tournament on players' physical performance, hormonal responses, muscle damage and recovery. J Sports Sci Med. 2013;12(2):240-8.

23. Chen C, Nosaka K, Chen H, Lin M, Tseng K, Chen T. Effects of flexibility training on eccentric exerciseinduced muscle damage. Med Sci Sports Exerc. 2011;43(3):491-500.

24. Howatson G, Hoad M, Goodall S, Tallent J, Bell P, French D. Exercise-induced muscle damage is reduced in resistance-trained males by branched chain amino acids: A randomized, double-blind, placebo controlled study. J Int Soc Sports Nutr. 2012;9(1):20.

25. Sikorski E, Wilson J, Lowery R, Joy J, Laurent C, Wilson S, et al. Changes in perceived recovery status scale following high-volume muscle damaging resistance exercise. J Strength Cond Res. 2013:27(8):2079-85.

26. West D, Cunningham D, Finn C, Scott P, Crewther B, CookC, et al. The metabolic, hormonal, biochemical and neuromuscular function responses to a backward sled drag training session. J Strength Cond Res. 2014;28(1):265-72.

27. Cadore E, Pinheiro E, Izquierdo M, Correa C, Radaelli R, Martins J, et al. Neuromuscular, hormonal, and metabolic responses to different plyometric training volumes in rugby players. J Strength Cond Res. 2013;27(11):3001-10.

28. Aboodarda S, George J, Mokhtar A, Thompson M. Muscle Strength and Damage Following Two Modes of Variable Resistance Training. J Sport Sci Med. 2011;10(4):635-42.

29. Silva Jr A, Campos M, Tomaz L, Bertucci D, Soares G, Rigo G, et al. Estudo do comportamento cortisol gh e insulina após uma sessão de exercício resistido agudo. Rev Bras Med Esporte. 2014;20(1):21-5

30. Schultz A, Moreira A, Nunes J, Viveiros L, Rose Jr D, Aoki M. Monitoring stress level of brazilian female basketball athletes during the preparation for the 2009 american cup. Rev Bras Med Esporte. 2013;19(1):44-7. 